The third set of problems too commonly overlooked concerns the degree to which the proper role of higher education in industrial communities such as Britain may be compromised by too headlong a pursuit of industrial liaisons. The ACARD report acknowledges some of these difficulties, but only to dismiss them. Impediments to free publication? "We feel it reasonable that the provider of funds should control the publication of results . . ." Applied research might dominate basic research? "... The current emphasis is the other way." Fears that one company may benefit at the expense of others? ". . . The return to the nation for its involvement in publicly sponsored research" comes from the taxes paid by the companies concerned, and from the employment their business create. The conflict between the pursuit of scholarship and the concerns of industry? "Such attitudes, where they exist, reflect the way in which industry and the academic world have failed to come together in the United Kindom . . ," These questions and answers overlook the seriousness of the problems that British universities need to contend with if (as is to be hoped) they find ways of contributing more directly to industrial innovation, and that now need to be examined closely not merely as academic issues but in the light of often painful experience elsewhere, in the United States for example.

Whatever ACARD says, the stampede for more industrial links with higher education will compromise the impartiality of the university as a source of advice to all comers, and safeguards need to be devised. The fact that a company enjoying a successful relationship with some university may in due course pay higher taxes will be little comfort to some other company denied access to the same source of assistance, while exclusivity as such is unlikely in the long run to benefit the British economy. Unfortunately, no one set of guidelines will cover all circumstances. Academic scientists working as consultants for private comapnies should be required to disclose their relationships not only to their colleagues but, if asked, to other companies. Academic innovators with something to patent should share the proceeds with their institutions, which should have responsibility for making sure that the patent goes to the company offering the best terms (but should not seek patent protection themselves). Academics and institutions carrying out projects under contracts with industrial organizations should ensure that the full costs (overheads as well as direct costs) are properly covered, and should be prepared to welcome supervision by the University Grants Committee to ensure that public funds are not thus used indirectly to support private enterprises. Much of this will seem needlessly irksome, yet explicit regulations of this kind are a necessary means of making sure that industrial liaisons prosper.

It is just as important that the principal function of higher education - the education of students - should not be compromised by the flourishing of industrial liaisons. The central issue is whether the universities, other institutions and their academics will be distracted from their central role by the search for extra revenue, marginal though it will usually be. Most institutions are aware of the danger, and on their guard against the obvious risks. There is, however, a hidden risk that needs attention. One of the ways in which the British economy is deficient in comparison with its competitors is that too few young people elect to pursue technical courses of study. There is ample evidence that both the proportions following technical courses and their enthusiasm for them are restricted by the demands at secondary schools for early specialization. (Only this week, a body called the Secondary Science Curriculum Review published its plan for changing all that.) The result is that the demand for technical education in higher education is less than would naturally be the case. In short, a more sensible way of introducing the school population to what science is and is about would dramatically increase demand for higher education in this field but also occasion structural changes. How, the universities should be asking themselves, would they be able to live with such a development, itself the best thing that could happen to British industry, and at the same time serve as prime movers in the process of industrial innovation? That, mercifully, is a question that cannot for much longer be put off.

\section{Unthinkable abilities}

\author{
The death of Herman Kahn is a sad loss to \\ realism in international affairs.
}

Herman Kahn, who died last week, was an enormous man, physically and in intellectual stamina. He was also one who deliberately provoked a reputation as an enfant terrible, and whose self-appointed role was to challenge the accepted beliefs of the liberal establishment to which, after the Second World War, and with his background at the California Institute of Technology, he might have been expected to belong. Instead, Kahn became a Rand Corporation man and then, with On Thermonuclear War (published in 1960 in a lurid red and yellow jacket) one who was commonly supposed to advocate nuclear warfare as a routine instrument of international relations. Kahn, of course, had said nothing of the kind - merely that those who pinned their faith in deterrence by nuclear weapons as an instrument of strategy should at least contemplate what might happen if they were compelled by their strategic doctrine to make use of them. His advocacy of building shelters for at least a proportion of the population was similarly understood to be a case for saying that nuclear warfare could be winnable in some absolute sense - a misunderstanding in retrospect understandable because of the density of Kahn's prose and because he set out arguments in note form, as if he were about to give a lecture studded with shocking aphorisms. The storm provoked by this book, which might have been more influential if it had been more subtle (but which might also then have become yet another treatise among a flood of others at that time), left Kahn unabashed. He went on to invent the phrase "think the unthinkable", the activity that became his stock in trade.

Kahn was in reality not the ogre public legend required. Surprisingly, he was also one of those congenital optimists given to bouts of depression by manifestations of the disbelief of others. This is the spirit in which he found it hard to come to terms with the widespread belief, common in the United States fifteen years ago, that economic growth must somehow be wicked and, a little later, the widespread indifference to the emergence of Japan as an industrial power. Kahn's perception of his role was that of a prophet most often ignored until too late.

Part of the trouble was his own impatience with conventional means of communication. Although capable of a fluent 55-minute talk on virtually any subject at the drop of a hat, he seemed curiously indifferent to the importance of verbs in written sentences, or the need to connect one sentence with the next. His style was that of one who had assembled numerical evidence from various unlikely places, who had perceived some conclusion buried in the data and who could not for the life of him understand why the same should not be true for his readers. But Kahn was often overwhelmed by the speed with which his own ideas came tumbling out, so that sentences had to be left unfinished because the next had already begun, and because he had succeeded in applying the vocabulary of lunch-room physics to international relations and national security. Even in later life, Kahn seemed to have kept the habits of a precocious but still not educated student whose more sober teachers whisper to each other that he may be too smart by half.

Kahn's most obvious legacy is the Hudson Institute in New York State, always more boisterous than the Rand Institute (and much smaller). Being so obviously Kahn's own thing, the institute may have some uncomfortable times ahead. But even for those who profoundly disagreed with him, Kahn's chief interest is that he preached what he considered to be realism at a time when realism was out of fashion. Kahn's unthinkables were not, after all, beyond the scope of thought but were merely outlawed by convention. It is admirable that a man so burdened by being overweight, and whose visits to various cities often took the form of checking into the nearest comfortable hotel to the airport and there holding court should have stirred up so much thought. Even Kahn's opponents will acknowledge that. 